\title{
PAS Positive
}

National Cancer Institute

\section{Source}

National Cancer Institute. PAS Positive. NCI Thesaurus. Code C162098.

An indication that a sample has detectable periodic acid-Schiff staining. 